\title{
Rotation with Cover Crops Suppresses Weeds and Increases Plant Density and Yield of Strawberry
}

\author{
Dennis N. Portz and Gail R. Nonnecke ${ }^{1}$ \\ Department of Horticulture, Iowa State University, 106 Horticulture Hall, \\ Ames, IA 50011-1100
} Additional index words. native plants, prairie plants, sustainable agriculture, replant disease,
Fragaria $\times$ ananassa

\begin{abstract}
Yield of strawberry grown continuously on the same site often declines over time as a result of proliferation of weed seeds and pathogenic organisms in the soil. Plots were established and maintained in seven different cover crops and as continuous strawberry or continuous tillage for 10 years $(1996$ to 2005$)$ in a site that was previously in strawberry production for 10 years (1986 to 1995). Cover crops included blackeyed Susan (Rudbeckia hirta L.), sorghum Sudangrass [Sorghum bicolor (L.) Moench], marigold (Tagetes erecta L.), big bluestem (Andropogon gerardii Vitman), perennial ryegrass (Lolium perenne $\mathrm{L}$.), switchgrass (Panicum virgatum $\mathrm{L}$.), and Indiangrass [Sorghastrum nutans $(\mathrm{L}$.) Nash]. Treatments were ended in 2005 and plots were planted with 'Honeoye' strawberry in a matted row. Effectiveness of soil pretreatments in reducing weed populations and enhancing strawberry production was evaluated for four growing seasons by quantifying weed growth by type and biomass and strawberry plant density and yield. The results indicate that matted-row strawberry production plots that were either in continuous tillage or established in $S$. bicolor, $P$. virgatum, or $A$. gerardii before planting strawberry had lower weed biomass and greater strawberry plant establishment and yield than plots established in $L$. perenne or $R$. hirta or that had supported continuous strawberry production.
\end{abstract}

Continuous strawberry production on the same site causes proliferation of weeds and accumulation of pathogens in the soil and subsequently decreases strawberry yield (LaMondia et al., 2002; Pritts and Handley, 1998). Continuous tillage to remove weeds breaks down soil particle size and causes compaction, consequently reducing crop vigor (Katsvairo et al., 2002; Kremer and Li, 2003). Cover crops grown before planting perennial fruit crops can alleviate the build up of weeds and pathogens in the soil (LaMondia et al., 2002; Merwin and Stiles, 1989; Seigies and Pritts, 2006; Shanks and Chamberlain, 1993) and can maintain soil structure (Nonnecke and Pritts, 2005). Chemical inputs such as methyl bromide have been used in strawberry production to reduce the impact of weeds and pathogens since the 1960s. However, under the Montreal Protocol and U.S. Clean Air Act, use of methyl bromide is restricted (EPA, 2011; Schneider et al., 2003). In strawberry production, weed control is difficult because not all weed species are controlled by labeled herbicides (Pritts and Handley, 1998). Growers can use pre-emergent herbicides to prevent weed seed growth and selective postemergent herbicides to control monocot weeds throughout the season. Controlling dicot weeds with postemergent herbicides is primarily limited to the

Received for publication 25 Apr. 2011. Accepted for publication 10 July 2011.

${ }^{1}$ To whom reprint requests should be addressed; e-mail nonnecke@iastate.edu. time of renovation (Bordelon et al., 2006). Alternative management practices are needed to reduce the impact of weeds and pathogens during strawberry production, and rotation with cover crops is a possible alternative.

Implementing cover crops before establishing a fruit crop has lowered weed and pathogenic organism populations in the soil and affected yield with differing results based on the cover crop grown. McKeown et al. (1994) showed that areas planted with $P$. virgatum, A. gerardii, $S$. nutans, and $R$. hirta had low counts of pathogenic nematodes in soil. Seigies and Pritts (2006) found similar results of reduced nematode populations and greater yield of strawberry in pots containing soil residue of $P$. virgatum, $S$. nutans, and $R$. hirta compared with fumigation or bare fallow soil. Ecosystems of prairie plants (polyculture) can reduce weed growth compared with tillage or continuous cropping (Kremer and Li, 2003). Sorghum bicolor rotated with strawberry showed low counts of weeds and pathogenic nematodes and fungi (Elmer, 1999; Kratochvil et al., 2004; LaMondia et al., 2002; McSorley and Gallaher, 1993). Tagetes erecta 'Crackerjack' incorporated into the soil releases biochemicals that can reduce pathogenic nematodes (BallCoelho et al., 2003; Merwin and Stiles, 1989; Reynolds et al., 2000; Topp et al., 1998). Planting $L$. perenne between strawberry rows reduced strawberry yield compared with plots that were continuously tilled (Shanks and Chamberlain, 1993), but the effects of $L$. perenne as a cover crop grown before strawberry are unknown. Seigies and Pritts (2006) showed increased yield of strawberries grown in pots of field soil incorporated with T. erecta compared with field soil that had been fumigated or was kept bare. They also showed an increased growth of strawberry and decreased weeds and pathogens in greenhouse potted strawberry when 1-year growth of monoculture prairie grasses was incorporated into field soil.

Five years or more without strawberry production on the same site is recommended to reduce soilborne pathogens in the Midwest without fumigation (Ellis et al., 2004). A limitation of using rotation cover crops as a management technique is the length of time that the area is unavailable for strawberry production. However, cover crop seeds from prairie plants and open-pollinated flowers can be harvested and sold as an alternative crop (Dinnes et al., 2002). Other cover crops can be established as forages or bedding intended for animal husbandry or as a crop for a biofuel energy source (Gibson and Barnhart, 2007).

Our experiment builds on previous research by providing a field study with longterm cover crops grown before strawberry to mitigate weeds and increase strawberry yield. The objectives of this study were to 1) evaluate weed populations by type and biomass; and 2) compare plant density and strawberry yield in plots after long-term continuous tillage, continuous strawberry, or growth with monoculture covers of $P$. virgatum, A. gerardii, L. perenne, S. nutans, R. hirta, S. bicolor, and $T$. erecta. Our hypothesis was plots established in cover crops or plots of continuous tillage would reduce weed populations and have greater strawberry plant density and yield compared with plots of continuous strawberry production.

\section{Materials and Methods}

The experiment was conducted from 1996 to 2008 at the Iowa State University (ISU) Horticulture Research Station (lat. $42^{\circ} 06^{\prime} 30^{\prime \prime}$ $\mathrm{N}$; long. $\left.93^{\circ} 35^{\prime} 08^{\prime \prime} \mathrm{W}\right)$. Soil was a Clarion loam with a $2 \%$ to $9 \%$ slope and categorized as a mixed mesic Typic Hapludoll with moderate drainage and high water-holding capacity (USDA, 1984). Initial soil samples before treatment establishment (in 1996) showed a pH of 6.4 and $2.8 \%$ organic matter in the site where strawberry plants were continuously grown in a matted-row system from 1986 to 1995.

Treatment plots were established 22 May 1996 in a randomized complete block design with three replications of nine plots that were $6.1 \mathrm{~m} \times 6.1 \mathrm{~m}$. Plots of $R$. hirta, $P$. virgatum, and $S$. nutans were seeded at $11.98 \mathrm{~kg} \cdot \mathrm{ha}^{-1}$ (Ion Exchange, Harper's Ferry, IA). Plots of T. erecta 'Crackerjack' were seeded at 5.68 $\mathrm{kg} \cdot \mathrm{ha}^{-1}$ (Stokes Seed, Fredonia, NY). Plots of $S$. bicolor 'Honey pasture' were seeded at $11.35 \mathrm{~kg} \cdot \mathrm{ha}^{-1}$ (Sexauer Company, Brookings, $\mathrm{SD})$. Plots of $L$. perenne were seeded at $34.05 \mathrm{~kg} \cdot \mathrm{ha}^{-1}$ (Sexauer Company). Plugs of $A$. gerardii were started in a greenhouse and planted in Summer 1996 because plots did not establish by seeding. Plots of $A$. gerardii, 
$P$. virgatum, $S$. nutans, and $L$. perenne were allowed to grow as perennials. Rudbeckia hirta was overseeded annually but not tilled. Tagetes erecta and S. bicolor plots were tilled and reseeded annually. Plots of continuous strawberry treatment were established with dormant 'Honeoye' crowns (Indiana Berry Company, Huntington, IN) planted $46 \mathrm{~cm}$ apart in five rows with 1-m spacing. Strawberry plants were mulched with Avena sativa (oat) straw at $8960 \mathrm{~kg} \cdot \mathrm{ha}^{-1}$ annually for overwintering. Plots receiving continuous tillage were cultivated monthly during the growing season and not allowed to establish plant cover. Prescribed burning was completed in all plots in the spring of 1997, 1998, and 2001 to encourage new growth of perennial cover crops.

Treatments were ended in Spring 2005 by prescribed burning surface plant debris to remove cover crop thatch for ease of tilling $15 \mathrm{~cm}$ into the soil. Plants of 'Honeoye' strawberry were placed in all plots $46 \mathrm{~cm}$ apart in five rows and $1 \mathrm{~m}$ between rows. Plants were mulched with oat straw at $8960 \mathrm{~kg} \cdot \mathrm{ha}^{-1}$ in November of 2005, 2006, and 2007 for overwintering. Straw mulch was moved to the area between the strawberry rows in the spring. Strawberry plants were irrigated $2.5 \mathrm{~cm}$ per week by rainfall or supplemental overhead irrigation. Renovation was conducted after harvest in July 2006 and July 2007 and included herbicide application of 2,4-D Formula 40 (Nufarm Americas, Inc., Burr Ridge, IL) 2,4dichlorophenoxyacetic acid, and DCPA, dimethyl tetrachloroterephthalate (Bordelon et al., 2006), leaf removal, narrowing of matted rows to $30.5 \mathrm{~cm}$, and tilling areas between the narrowed matted row according to methods from Pritts and Handley (1998). All treatment plots were fertilized in 2005, 2006, and 2007 at $56 \mathrm{~kg} \cdot \mathrm{ha}^{-1}$ of nitrogen $(\mathrm{N})$ in the first 2 weeks of July (after renovation) and at $34 \mathrm{~kg} \cdot \mathrm{ha}^{-1}$ of $\mathrm{N}$ in the last 2 weeks of August by hand over the strawberry rows.

Type and biomass of weeds were collected 6 June, 1 July, and 9 Aug. 2005; 19 May and 30 Aug. 2006; and 21 May and 26 Aug. 2007. Monocot and dicot weeds were collected separately from three random $50 \mathrm{~cm} \times 50-\mathrm{cm}$ quadrats placed over the strawberry row within each plot. Roots were discarded, and shoots were dried for $72 \mathrm{~h}$ at $67^{\circ} \mathrm{C}$. Weeds not collected for observations were killed within 1 week by tillage or spot treatment with herbicide [glyphosate, N-(phosphonomethyl)glycine] applied with a hand wick applicator and then pre-emergent herbicide was applied (DCPA, dimethyl tetrachloroterephthalate) (Bordelon et al., 2006).

Strawberry plants for sampling of rootlesion nematodes were collected 25 Oct. 2005, 30 Oct. 2006, and 17 Nov. 2007. Nematode populations were determined by harvesting three random strawberry plants from each plot. Nematodes were extracted from washed roots placed into a $125-\mathrm{mL}$ flask containing $50 \mathrm{~mL}$ of streptomycin sulfate-mercuric chloride extraction solution and shaken for $96 \mathrm{~h}$ (Charlson and Tylka, 2003). Lesion nematodes were enumerated with a dissecting microscope as number per dry gram of root biomass.
Initial transplant establishment was determined in July 2005 by counting the number of dead plants per row in each plot 1 month after planting. Density of established strawberry plants was measured 21 Oct. 2005, 27 Nov. 2006, and 17 Nov. 2007 and determined by counting the rooted parent and runner plants in three random $50 \mathrm{~cm} \times 50-\mathrm{cm}$ quadrats placed over the strawberry row within each plot.

Total yield of strawberry was measured biweekly from 3 June to 26 June 2006, 31 May to 12 June 2007, and 13 June to 23 June 2008. Fruits were harvested, counted, and weighed from three areas that were $0.66 \mathrm{~m} \times 1.66 \mathrm{~m}$ within the row in each plot. Fungicide (Captan, N-trichloromethyltio-4-cyclohexene-1,2dicarboximide) was applied at 5\% and 50\% bloom on all plots (Bordelon et al., 2006).

Data were analyzed using general linear model (PROC GLM) of SAS 9.1 (SAS Institute, 2002-2003) to determine analysis of variance for tests of significance, and means were separated using Fisher's protected least significant difference test $(P \leq 0.05)$.

\section{Results and Discussion}

Rotation with cover crops and continuous cultivation before planting strawberry generally reduced weed populations and increased strawberry plant density and yield compared with continuous strawberry in these field studies (Tables 1-4). Strawberry plants grown continuously in the same plots and on the same site exhibited low strawberry plant density and fruit yield and high weed populations. These results were consistent with previous research (Pritts and Handley, 1998; Seigies and Pritts, 2006).

Analysis of variance showed significant treatment $\times$ time interactions for all variables. Therefore, data were analyzed separately by month for monocot and dicot weed biomass in each year and by year for strawberry plant density and yield.

Weeds in the spring (May and June in the Midwest) reduce plant and fruit growth, pollinator activity, ease of fruit harvest, and customer satisfaction where customers pick their own berries (Ellis et al., 2004). In August, competition from weeds reduces plant growth and the development of flowers for the next year's yield in short-day strawberry cultivars.

The most commonly occurring monocot weeds in plots in 2005 through 2007 during strawberry establishment and production were giant foxtail (Setaria faberi Herrm.), common oat (Avena sativa L.), large crabgrass [Digitaria sanguinalis (L.) Scop.], quackgrass [Elymus repens (L.) Gould], and orchardgrass (Dactylis glomerata L.). The most common dicot weeds in the same plots and time were

Table 1. Dry biomass of monocot weeds after 9 years of cover crops, continuous tillage, or continuous strawberry (Fragaria ×ananassa) in 2005, 2006, and 2007.

\begin{tabular}{|c|c|c|c|c|c|c|c|}
\hline \multirow[b]{3}{*}{ Treatment } & \multicolumn{7}{|c|}{ Dry biomass of monocot weeds $(\mathrm{g} / 50 \mathrm{~cm} \times 50$-cm area) } \\
\hline & \multicolumn{3}{|c|}{$2005^{z}$} & \multicolumn{2}{|c|}{2006} & \multicolumn{2}{|c|}{2007} \\
\hline & June & July & Aug. & May & Aug. & May & Aug. \\
\hline Continuous strawberry & $3.2^{\mathrm{yx}} \mathrm{cd}$ & $0.9 \mathrm{c}$ & $14.6 \mathrm{ab}$ & $3.7 \mathrm{c}$ & $26.0 \mathrm{a}$ & $5.7 \mathrm{a}$ & $31.1 \mathrm{a}$ \\
\hline Continuous tillage & $1.1 \mathrm{e}$ & $4.0 \mathrm{a}$ & $2.8 \mathrm{bc}$ & $0.6 \mathrm{c}$ & $1.2 \mathrm{c}$ & $0.5 \mathrm{~b}$ & $5.8 \mathrm{~b}$ \\
\hline Rudbeckia hirta & $7.6 \mathrm{a}$ & $1.9 \mathrm{bc}$ & $15.6 \mathrm{a}$ & $10.3 \mathrm{~b}$ & $7.8 \mathrm{bc}$ & $2.2 \mathrm{ab}$ & $7.2 \mathrm{~b}$ \\
\hline Sorghum bicolor & $2.7 \mathrm{cde}$ & $2.6 \mathrm{abc}$ & $5.5 \mathrm{abc}$ & $0.6 \mathrm{c}$ & $1.4 \mathrm{c}$ & $0.5 \mathrm{~b}$ & $14.0 \mathrm{ab}$ \\
\hline Tagetes erecta & $3.8 \mathrm{bc}$ & $2.1 \mathrm{abc}$ & $10.3 \mathrm{abc}$ & $0.5 \mathrm{c}$ & $1.6 \mathrm{c}$ & $0.9 \mathrm{~b}$ & $28.5 \mathrm{a}$ \\
\hline Andropogon gerardii & $3.7 \mathrm{bc}$ & $2.0 \mathrm{bc}$ & $3.3 \mathrm{bc}$ & $1.8 \mathrm{c}$ & $1.9 \mathrm{c}$ & $2.1 \mathrm{ab}$ & $20.1 \mathrm{ab}$ \\
\hline Lolium perenne & $5.2 \mathrm{~b}$ & $2.9 \mathrm{ab}$ & $2.2 \mathrm{c}$ & $21.7 \mathrm{a}$ & $13.9 \mathrm{~b}$ & $4.2 \mathrm{ab}$ & $15.7 \mathrm{ab}$ \\
\hline Panicum virgatum & $1.5 \mathrm{de}$ & $2.0 \mathrm{bc}$ & $0.1 \mathrm{c}$ & $0.1 \mathrm{c}$ & $0.4 \mathrm{c}$ & $1.5 \mathrm{ab}$ & $33.1 \mathrm{a}$ \\
\hline Sorghastrum nutans & $4.1 \mathrm{bc}$ & $1.4 \mathrm{bc}$ & $3.0 \mathrm{bc}$ & $0.8 \mathrm{c}$ & $4.9 \mathrm{bc}$ & $0.4 \mathrm{~b}$ & $30.5 \mathrm{a}$ \\
\hline
\end{tabular}

${ }^{\mathrm{z}} 2005$ = year of matted row establishment; 2006 and 2007 = years of production.

${ }^{y}$ Mean of nine randomly selected $50 \mathrm{~cm} \times 50-\mathrm{cm}$ experimental units per treatment.

${ }^{\mathrm{x}}$ Means followed by the same letter within columns are not different from each other based on Fisher's protected least significant difference test $(P \leq 0.05)$.

Table 2. Dry biomass of dicot weeds after 9 years of cover crops, continuous tillage, or continuous strawberry (Fragaria $\times$ ananassa) in 2005, 2006, and 2007.

\begin{tabular}{|c|c|c|c|c|c|c|c|}
\hline \multirow[b]{3}{*}{ Treatment } & \multicolumn{7}{|c|}{ Dry biomass of dicot weeds $(\mathrm{g} / 50 \mathrm{~cm} \times 50-\mathrm{cm}$ area $)$} \\
\hline & \multicolumn{3}{|c|}{$2005^{z}$} & \multicolumn{2}{|c|}{2006} & \multicolumn{2}{|c|}{2007} \\
\hline & June & July & Aug. & May & Aug. & May & Aug. \\
\hline Continuous strawberry & $2.7^{\mathrm{yx}} \mathrm{ab}$ & $2.7 \mathrm{a}$ & $22.7 \mathrm{a}$ & $20.8 \mathrm{ab}$ & $17.6 \mathrm{a}$ & $24.9 \mathrm{a}$ & $34.9 \mathrm{a}$ \\
\hline Continuous tillage & $0.4 \mathrm{~cd}$ & $1.0 \mathrm{bc}$ & $0.8 \mathrm{c}$ & $2.4 \mathrm{c}$ & $0.1 \mathrm{~d}$ & $0.4 \mathrm{c}$ & $14.5 \mathrm{bc}$ \\
\hline Rudbeckia hirta & $1.7 \mathrm{bc}$ & $1.0 \mathrm{bc}$ & $3.8 \mathrm{c}$ & $30.8 \mathrm{a}$ & $4.2 \mathrm{~cd}$ & $7.9 \mathrm{bc}$ & $8.2 \mathrm{bc}$ \\
\hline Sorghum bicolor & $0.3 \mathrm{~d}$ & $0.4 \mathrm{c}$ & $2.2 \mathrm{c}$ & $0.1 \mathrm{c}$ & $2.8 \mathrm{~cd}$ & $6.9 \mathrm{bc}$ & $5.4 \mathrm{c}$ \\
\hline Tagetes erecta & $1.5 \mathrm{bcd}$ & $1.1 \mathrm{bc}$ & $1.7 \mathrm{c}$ & $7.1 \mathrm{bc}$ & $9.5 \mathrm{bc}$ & $7.5 \mathrm{bc}$ & $5.7 \mathrm{c}$ \\
\hline Andropogon gerardii & $1.4 \mathrm{bcd}$ & $1.7 \mathrm{abc}$ & $8.9 \mathrm{bc}$ & $4.0 \mathrm{bc}$ & $1.1 \mathrm{~d}$ & $6.6 \mathrm{bc}$ & $14.0 \mathrm{bc}$ \\
\hline Lolium perenne & $1.3 \mathrm{~cd}$ & $2.5 \mathrm{ab}$ & $20.2 \mathrm{a}$ & $20.7 \mathrm{ab}$ & $14.3 \mathrm{ab}$ & $11.9 \mathrm{~b}$ & $22.9 \mathrm{ab}$ \\
\hline Panicum virgatum & $3.5 \mathrm{a}$ & $1.6 \mathrm{abc}$ & $4.7 \mathrm{c}$ & $1.2 \mathrm{c}$ & $6.3 \mathrm{~cd}$ & $4.4 \mathrm{bc}$ & $7.7 \mathrm{bc}$ \\
\hline Sorghastrum nutans & $1.3 \mathrm{~cd}$ & $1.8 \mathrm{abc}$ & $18.2 \mathrm{ab}$ & $11.2 \mathrm{bc}$ & $4.1 \mathrm{~cd}$ & $6.3 \mathrm{bc}$ & $5.7 \mathrm{c}$ \\
\hline
\end{tabular}

${ }^{\mathrm{z}} 2005$ = year of matted row establishment; 2006 and $2007=$ years of production.

${ }^{\mathrm{y}}$ Mean of nine randomly selected $50 \mathrm{~cm} \times 50$-cm experimental units per treatment.

${ }^{\mathrm{x}}$ Means followed by the same letter within columns are not different from each other based on Fisher's protected least significant difference test $(P \leq 0.05)$. 
Table 3. Plant density of strawberry (Fragaria xananassa) after 9 years of cover crops, tillage, or continuous strawberry in Fall 2005, 2006, and 2007.

\begin{tabular}{lccc}
\hline & \multicolumn{3}{c}{ Plant density (plants per 50 cm $\times 50-\mathrm{cm}$ area) } \\
\cline { 2 - 4 } Treatments & $2005^{\mathrm{z}}$ & 2006 & 2007 \\
\hline Continuous strawberry & $7^{\mathrm{yx}} \mathrm{b}$ & $11 \mathrm{~b}$ & $2 \mathrm{~d}$ \\
Continuous tillage & $14 \mathrm{a}$ & $22 \mathrm{a}$ & $10 \mathrm{bc}$ \\
Rudbeckia hirta & $9 \mathrm{~b}$ & $22 \mathrm{a}$ & $8 \mathrm{c}$ \\
Sorghum bicolor & $14 \mathrm{a}$ & $22 \mathrm{a}$ & $17 \mathrm{a}$ \\
Tagetes erecta & $13 \mathrm{a}$ & $21 \mathrm{a}$ & $15 \mathrm{ab}$ \\
Andropogon gerardii & $13 \mathrm{a}$ & $22 \mathrm{a}$ & $10 \mathrm{bc}$ \\
Lolium perenne & $4 \mathrm{c}$ & $10 \mathrm{~b}$ & $9 \mathrm{c}$ \\
Panicum virgatum & $14 \mathrm{a}$ & $26 \mathrm{a}$ & $10 \mathrm{bc}$ \\
Sorghastrum nutans & $13 \mathrm{a}$ & $21 \mathrm{a}$ & $13 \mathrm{abc}$ \\
\hline
\end{tabular}

z2005 = year of matted row establishment; 2006 and 2007 = years of production.

${ }^{\mathrm{y}}$ Mean number of rooted plants in nine randomly selected $50 \mathrm{~cm} \times 50-\mathrm{cm}$ experimental units per treatment after renovation.

${ }^{x}$ Means followed by the same letter within columns are not different from each other based on Fisher's protected least significant difference test $(P \leq 0.05)$

Table 4. Yield of strawberry (Fragaria $\times$ ananassa) after 9 years of cover crops, tillage, or continuous strawberry in 2006, 2007, and 2008.

\begin{tabular}{llcr}
\hline & \multicolumn{3}{c}{ Yield $(\mathrm{kg} / 0.66 \mathrm{~m} \times 1.66 \mathrm{~m})$} \\
\cline { 2 - 4 } Treatment & $2006^{\mathrm{z}}$ & 2007 & 2008 \\
\hline Continuous strawberry & $0.63^{\mathrm{yx}} \mathrm{d}$ & $0.07 \mathrm{~d}$ & $0.11 \mathrm{c}$ \\
Continuous tillage & $1.99 \mathrm{ab}$ & $1.03 \mathrm{bc}$ & $0.61 \mathrm{bc}$ \\
Rudbeckia hirta & $1.22 \mathrm{c}$ & $0.93 \mathrm{c}$ & $0.43 \mathrm{bc}$ \\
Sorghum bicolor & $2.00 \mathrm{ab}$ & $1.67 \mathrm{a}$ & $1.33 \mathrm{a}$ \\
Tagetes erecta & $1.97 \mathrm{ab}$ & $1.46 \mathrm{a}$ & $0.40 \mathrm{bc}$ \\
Andropogon gerardii & $1.99 \mathrm{ab}$ & $1.07 \mathrm{bc}$ & $0.86 \mathrm{ab}$ \\
Lolium perenne & $0.58 \mathrm{~d}$ & $0.89 \mathrm{c}$ & $0.50 \mathrm{bc}$ \\
Panicum virgatum & $2.30 \mathrm{a}$ & $1.35 \mathrm{ab}$ & $0.93 \mathrm{ab}$ \\
Sorghastrum nutans & $1.58 \mathrm{bc}$ & $1.53 \mathrm{a}$ & $0.78 \mathrm{~b}$ \\
\hline
\end{tabular}

${ }^{2} 2005$ = year of matted row establishment; 2006 and 2007 = years of production.

${ }^{y}$ Mean kilograms per linear row area $(0.66 \mathrm{~m} \times 1.66 \mathrm{~m})$ in nine experimental units per treatment.

${ }^{x}$ Means followed by the same letter within columns are not different from each other based on Fisher's protected least significant difference test $(P \leq 0.05)$

lambsquarters (Chenopodium album L.), redroot pigweed (Amaranthus retroflexus L.), common purslane (Portulaca oleracea L.), Canada thistle [Cirsium arvense (L.) Scop.], and common dandelion (Taraxacum officinale F.H. Wigg.).

Biomass of monocot weeds generally was lower in spring (May and June) in plots of continuous tillage or rotated with $S$. bicolor, $T$. erecta, and $S$. nutans (Table 1). Plots rotated with $L$. perenne and $R$. hirta generally had greater biomass of monocot weeds in the spring. In August, monocot weed biomass generally was higher in continuous strawberry and lower in continuous tillage.

Dicot weed biomass generally was lowest in continuous tillage and plots rotated with A. gerardii, T. erecta, S. bicolor, and S. nutans in the spring, which is consistent with the results of Kremer and Li (2003) that showed prairie ecosystems had reduced weed populations (Table 2). Biomass of dicot weeds in August generally was lower in continuous tillage and plots rotated with $R$. hirta, $T$. erecta, $S$. bicolor, A. gerardii, and $P$. virgatum but greater in continuous strawberry and plots rotated with L. perenne. Strawberry plots rotated with $S$. bicolor showed results similar to those of LaMondia et al. (2002) who reported reduced total weed populations in strawberry. Reduced weed biomass found in continuously tilled plots or plots rotated with $S$. bicolor or $T$. erecta that were tilled annually for seeding suggests a reduction of the weed seed bank in the soil. Panicum virgatum, a perennial, covers the soil surface and reduces weed seed germination and growth. Plots rotated with $L$. perenne and those in continuous strawberry had high dicot weed biomass over all years in this study. High dicot weed pressure creates challenges to strawberry producers who have limited resources, insufficient time, and ineffective herbicides to control dicot weeds (Pritts and Handley, 1998).

Average lesion nematode counts were below 10 per $g$ of dry root biomass for all treatments from all 3 years. Low lesion nematode counts were found in plots rotated with A. gerardii, $P$. virgatum, $S$. nutans, and $R$. hirta, similar to those reported by McKeown et al. (1994). However, plots of continuous strawberry also showed low counts of lesion nematodes. We conclude that populations of lesion nematodes in the test area were too low to determine if the treatments influenced their control and were not considered detrimental to the strawberry plants in this study.

In 2005, 2006, and 2007, strawberry plant density was lower in plots of continuous strawberry and in plots rotated with $L$. perenne than in plots rotated with $S$. bicolor or $T$. erecta (Table 3). In July 2005, strawberry transplant mortality was $24 \%$ and $11 \%$ in plots rotated with $L$. perenne and $R$. hirta, respectively, whereas all other plots incurred less than $1 \%$ strawberry transplant mortality. Young dying plants showed symptoms of wilting, necrosis of oldest leaves, and meristem death. Disease symptoms were diagnosed visually by ISU pathologists as symptomatic of verticillium wilt (Verticillium spp.) (Maas, 1998). Results of high transplant fatality in plots rotated with $L$. perenne are consistent with the observations by Shanks and Chamberlain (1993) who showed that $L$. perenne adversely affects strawberry growth. It is unknown if soilborne diseases increase in strawberry production when residues of $L$. perenne are present.

Yield of strawberry generally was highest in the plots rotated with $S$. bicolor and $P$. virgatum and lowest in plots of continuous strawberry and plots rotated with $L$. perenne and $R$. hirta (Table 4). Higher yields of strawberry in plots rotated with $P$. virgatum are similar to the findings of Seigies and Pritts (2006) in pot-culture studies of strawberry.

Plots of continuous tillage or rotated with $S$. bicolor, $P$. virgatum, and $A$. gerardii had reduced weeds, which coincided with greater plant establishment and yield of strawberry compared with plots rotated with $L$. perenne and $R$. hirta or to plots in continuous strawberry production. Although continuous tillage reduced weeds effectively in this study, over many years with no cover, it can increase soil erosion, soil compaction, and nutrient leaching. Our findings show that $S$. bicolor, $P$. virgatum, and $A$. gerardii are superior cover crops for use in rotation with strawberry, and their use may reduce soil deterioration by avoiding tillage.

Effects of short-term treatments and combinations of species mix on pests, soil, and subsequent strawberry growth may influence the benefits and challenges of rotating with cover crops. Further work should investigate the effects of short-term rotations using $S$. bicolor, $P$. virgatum, and $A$. gerardii or their combinations as polyculture in rotation with strawberry. The negative aspects associated with $L$. perenne as a rotational cover crop should be further clarified.

\section{Literature Cited}

Ball-Coelho, B., A. Bruin, and E. Riga. 2003 Forage pearl millet and marigold as rotation crops for biological control of root-lesion nematodes in potato. Agron. J. 95:282-292.

Bordelon, B., M. Ellis, and R. Foster. 2006. Midwest commercial small fruit and grape spray guide. Iowa State Univ. Ext. Bul. PM 1375:61-63.

Charlson, D. and G. Tylka. 2003. Heterodera glycines cyst components and surface disinfectants affect $H$. glycines hatching. J. Nematol. 35:458-464.

Dinnes, D., D. Karlen, D. Jaynes, T. Kaspar, J. Hatfield, T. Colvin, and C. Cambardella. 2002. Nitrogen management strategies to reduce nitrate leaching in tile-drained Midwestern soils. Agron. J. 94:153-171.

Ellis, M., C. Welty, R. Funt, D. Doohan, R. Williams, M. Brown, and B. Bordelon. 2004. Midwest small fruit pest management handbook. Ohio State Univ. Bul. 861.

Elmer, W. 1999. Influence of ammonium sulfate and rotation crops on strawberry black root rot. Plant Dis. 83:119-123. 
EPA. 2011. Methyl bromide; notice of receipt of requests to voluntarily amend registrations to terminate certain soil uses. Fed. Regist. 76:7200 7203.

Gibson, L. and S. Barnhart. 2007. Switchgrass. Iowa State Univ. Bul. Ag200.

Katsvairo, T., W. Cox, and H. Van Es. 2002. Tillage and rotation effects on soil physical characteristics. Agron. J. 94:299-304.

Kratochvil, R., S. Sardanelli, K. Everts, and E. Gallagher. 2004. Evaluation of crop rotation and other cultural practices for management of root-knot and lesion nematodes. Agron. J. 96: 1419-1428.

Kremer, R. and J. Li. 2003. Developing weedsuppressive soils through improved soil quality management. Soil Tillage Res. 72:193-202.

LaMondia, J., W. Elmer, T. Mervosh, and R. Cowles. 2002. Integrated management of strawberry pests by rotation and intercropping. Crop Prot. 21:837-846

Maas, J. 1998. Compendium of strawberry diseases. 2nd Ed. Amer. Phytopath. Soc. Press, St. Paul, MN.
McKeown, A., J. Potter, M. Gartshore, and P. Carson. 1994. A note on the occurrence of root lesion nematodes under sand-prairie species in the regional municipality of HaldimandNorfolk, Ontario. Phytoprotection 75:139142.

McSorley, R. and R. Gallaher. 1993. Population dynamics of plant-parasitic nematodes on cover crop of corn and sorghum. J. Nematol. 25:446453.

Merwin, I. and W. Stiles. 1989. Root-lesion nematode, potassium deficiency, and prior cover crops as factors in apple replant disease. HortScience 114:724-728.

Nonnecke, G. and M. Pritts. 2005. Sustainable strawberry production and management, $p$ 84-96. In: Khanizadeh, S. and J. DeEll (eds.). Our strawberries. Public Works and Government Services Canada, Publishing and Depository Services, Ottawa, Ontario, Canada.

Pritts, M. and D. Handley. 1998. Strawberry production guide for the Northeast, Midwest, and eastern Canada. Northeast Regional Agricultural Engineering Service, Ithaca, NY.
Reynolds, B., J. Potter, and B. Ball-Coelho. 2000. Crop rotation with Tagetes $\mathrm{sp}$. is an alternative for control of root-lesion nematodes. Agron. J. 92:957-966

SAS Institute. 2002-2003. SAS 9.1. SAS Institute Inc., Cary, NC.

Schneider, S., E. Rosskopf, J. Leesch, D. Chellemi, C. Bull, and M. Mazzola. 2003. USDA-ARS research on alternatives to methyl bromide: Pre-plant and post-harvest. Pest Manag. Sci. 59:814-826

Seigies, A. and M. Pritts. 2006. Cover crop rotations alter soil microbiology and reduce replant disorders in strawberry. HortScience 41:1303-1308.

Shanks, C. and J. Chamberlain. 1993. Strawberry fruit yield and vegetative growth and pest populations in plantings with and without cover crops. HortScience 28:1172-1173.

Topp, E., S. Millar, H. Bork, and M. Welsh. 1998. Effects of marigold (Tagetes sp.) roots on soil microorganisms. Biol. Fertil. Soils 27:149-154.

USDA. 1984. Soil survey of Story County, Iowa. Soil Conservation Service, U.S. Government Printing Office, Washington D.C., 149 p. 